\begin{tabular}{|c|c|c|c|c|}
\hline Submission & Review Process & Revised & Accepted & Published \\
\hline $21-05-2020$ & $01-06 \mathrm{~s} / \mathrm{d} 23-07-2020$ & $20-08-2020$ & $25-08-2020$ & $28-08-2020$ \\
\hline
\end{tabular}

Published by: Politik Islam UIN Raden Fatah Palembang

\title{
Sikap Politik Masyarakat Muslim Kecamatan Ilir Timur II Kota Palembang dalam Pileg Tahun 2019
}

\author{
Ahmad Syafi'i Arief \\ Fakultas Adab dan Humaniora Universitas Islam Negeri Raden Fatah Palembang \\ Email: Syafiiarief9904@gmail.com
}

\section{Syawaluddin}

Fakultas Adab dan Humaniora Universitas Islam Negeri Raden Fatah Palembang

Email: mohammadsyawaludin_uin@radenfatah.ac.id

\section{Leo Andiguna}

Fakultas Adab dan Humaniora Universitas Islam Negeri Raden Fatah Palembang

Email: leoandiguna_uin@radenfatah.ac.id

\begin{abstract}
This study is to determine the Political Attitudes of the Muslim Community in Ilir Timur II District in the 2019 Palembang City Legislative Election. The population in this study is the Muslim community in Ilir Timur II District, Palembang City. The sampling technique used in this study was simple random sampling of 100 people. This research uses descriptive quantitative method with a Likert scale measuring instrument. All statistical calculations were performed using the SPSS version 20.00 for windows computer assistance. Based on the results of the study, it can be concluded that the components of political attitudes consist of cognitive, affective, evaluative components, cognitive components which concern the knowledge of the Muslim community about politics and belief in politics, its role. The affective component of the Muslim community in Ilir Timur II District is to see the feelings of the Muslim community towards themselves as voters, attitudes towards legislative candidate candidates, attitudes towards the bearer party, assessment of the organizers. evaluative components are decisions and opinions
\end{abstract}


about political objects that typically display a combination of standard values and criteria with information and feelings.

Keywords: political behavior, general election, democracy

\begin{abstract}
ABSTRAK
Penelitian ini adalah untuk mengetahui Sikap Politik Masyarakat Muslim di Kecamatan Ilir Timur II Dalam Pemilihan Umum Legislatif Kota Palembang Tahun 2019. Populasi dalam penelitian ini adalah masyarakat muslim di Kecamatan Ilir Timur II Kota Palembang. Teknik pengambilan sampel yang digunakan dalam penelitian ini adalah simple random sampling sebanyak 100 masyarakat. Penelitian ini menggunakan metode kuantitatif deskriptif dengan alat ukur skala likert. Keseluruhan perhitungan statistik dilakukan dengan menggunakan bantuan komputer program SPSS versi 20.00 for windows. Berdasarkan hasil penelitian dapat disimpulkan bahwa komponen sikap politik terdiri dari komponen kognitif, afektif, evaluatif, Komponen kognitif ialah yang menyangkut pengetahuan masyarakat muslim tentang politik dan kepercayaan pada politik, peranan nya. komponen afektif masyarakat muslim di Kecamatan Ilir Timur II adalah dengan melihat perasaan masyarakat muslim terhadap dirinya sebagai pemilih, sikap terhadap kadidat calon anggota legislatif, sikap terhadap partai pengusung, penilaian terhadap penyelengara. komponen evaluatif adalah keputusan dan pendapat tentang objek-objek politikyang secara tipikal melihatkan kombinasi standar nilai dan kriteria dengan informasi dan perasaan.
\end{abstract}

Keywords: perilaku politik, pemilihan umum legislative, demokrasi

\title{
PENDAHULUAN
}

Pemilihan Umum legislatif telah diadakan pada 17 April 2019 lalu dan di tujukan untuk memilih para calon DPR, DPRD Kota maupun Provinsi dan DPD. Pemilihan Umum Legislatif sendiri dilaksanakan berdasarkan UU no. 7 tahun 2017. Menurut Sutisna Indonesia merupakan negara yang menganut sistem demokrasi yang artinya Indonesia menganut sistem pemerintahan dari rakyat (Sutisna, 2014). Lincoln menjelaskan bahwa demokrasi merupan suatu pemerintahan dari rakyat oleh rakyat dan untuk rakyat, demokrasi sangat erat kaitannya dengan politik sehingga rakyat tidak lepas dari partisipasi politik (Sarina. Dkk, 2016). Partisipasi merupakan salah satu aspek yang sangat penting dalam pesta demokrasi.

Partisipasi politik merupakan keikutertaan warga Negara biasa dalam menentukan segala keputusan yang menyangkut atau mempengaruhi hidupnya. Partisipasi dalam politik merupakan salah satu hak warga Negara dalam menjalankan prinsip-prinsip demokrasi. Salah satu partisipasi politik yang dimiliki rakyat adalah hak memberikan suara pada saat pemilihan umum (pemilu) berlangsung (Subakti,2010). 
Suatu pemilu dikatakan sukses tidak hanya dilihat dari terlaksananya semua tahapan sampai terisinya jabatan-jabatan yang di pilih. Tidak dapat dikatakan sebagai pemilu yang berhasil jika mereka terpilih melalui cara-cara yang penuh dengan pelanggaran dan kecurangan yang bertentangan dengan azaz Luber dan Jurdil.(Pamungkas, Sigit:2010). Salah satu cara dalam menentukan siapa yang berhak menjadi anggota Legislatif adalah dengan dilaksanakannya pemilihan umum (pemilu). Melalui pemilu memungkinkan semua pihak bisa terakomodasi apa yang diinginkan dan dicita-citakan sehingga terwujud kehidupan yang lebih baik.

Dari serangkaian proses politik dari sejak zaman reformasi sampai pemilu 2019 kemarin pasti ada proses perubahan-perubahan pertimbangan yang mendasari sikap politik masyarakat. Perubahan pilihan inilah yang menarik untuk diteliti lebih spesifiknya mengapa setiap pemilunya pilihan masyarakat berbeda-beda dalam setiap pemilunya. Kegiatan sehari-hari yang dilakukan oleh manusia, menurut para psikolog sosial, dikategorikan sebagai kegiatan yang "tidak lagi dipikirkan" (Langer, Blank, dan Chanowitz, 1978 dalam Petty dan Cacioppo, 1981). Oleh karena itu, kegiatan yang merupakan rutinitas tersebut kurang bisa diprediksi dengan berdasarkan pada sikap individu terhadap kegiatan tersebut. Namun demikian, sikap merupakan salah satu prediktor tingkah laku yang baik terhadap suatu objek sikap dalam kondisi tertentu (Ajzen dan Fishbein, 1971 dalam Petty dan Cacioppo, 1981). Contohnya seperti sikap terhadap Pemilu, mengingat Pemilu merupakan suatu kegiatan yang hanya terjadi satu kali dalam kurun waktu lima tahun.

Sikap adalah sebuah pengalaman yang terkait dengan objek yang spesifik, kejadian, orang-orang atau isu, dan sangat evaluatif. Kedua peneliti tersebut juga menyebutkan bahwa terdapat dua sudut pandang yang dimiliki oleh para peneliti psikologi sosial tentang sikap yaitu:

a. Sikap sebagai sebuah mental files yang tersimpan dalam ingatan dan dapat digunakan sewaktu-waktu.

b. Sikap sebagai sebuah penilaian yang bersifat evaluatif berdasarkan pada informasi yang didapatkan pada situasi saat itu.

Berdasarkan hasil observasi yang telah peneliti lakukan pada tanggal 10 November 2019, pada beberapa masyarakat yang ada di Kecamatan Ilir Timur II Kota Palembang,dapat dikatakan mereka memiliki pilihan yang berbeda pada setiap pemilihan umum legislatif yang telah dilaksanakan, karena dalam setiap pemilunya mereka memiliki pandangan yang berbeda-beda terhadap calon anggota legislatif yang ada, mulai dari faktor internal seperti ideologi dan pandangan sendiri terhadap calon anggota legislatif tersebut. Sedangkan faktor eksternalnya ialah mulai dari perbeda partai politik maupun faktor lingkunganya. Hal inilah yang membuat perlunya penelitian untuk mengetahui sikap politik masyarakat dalam setiap terjadinya proses pemilihan umum Legislatif (Pemilu).

Dari sudut pandang tersebut dapat dilihat bahwa sikap dapat terbentuk melalui pengalaman individu terhadap suatu objek sikap. Sikap, menurut Smith (1947), Memiliki tiga buah komponen yaitu afektif (affective), Kognitif (cognitive), dan konatif (central tendency). Sikap menjadi penting untuk diperhatikan lebih lanjut karena dapat mempengaruhi respon afektif, kognitif, dan konasi seseorang (Bohner \& Wanke, 2002). 
Selain itu, masih menurut peneliti yang sama, sikap seseorang terhadap satu objek sikap dapat mempengaruhi tingkah lakunya terhadap objek sikap lainnya. Sikap yang dimiliki oleh individu dapat terbentuk dari pengalaman maupun informasi yang di dapatkan oleh individu terkait objek sikap.

Terdapat beberapa pendekatan yang digunakan dalam teori pembentukan sikap. Salah satu dari pendekatan tersebut yaitu social judgmental-involvement approach. Pendekatan ini memiliki asumsi dasar bahwa setiap orang melakukan pengelompokan suatu stimulus secara teratur berdasarkan sebuah dimensi psikologis (Petty \& Cacioppo, 1981). Hal tersebut dapat disebut juga sebagai kategorisasi. Sikap individu terhadap suatu objek sikap dikelompokkan ke dalam tiga kategori, yaitu favorable, netral, dan unfavorable. Dalam proses kategorisasi untuk membentuk sikap, seseorang memerlukan informasi, pengalaman, dan waktu untuk belajar dan mencari informasi mengenai isuisu yang terkait.

Seperti yang telah dilaksanakan bersama pada tanggal 17 april 2019 yang lalu merupakan pesta demokrasi lima tahunan yaitu pemilihan umum anggota legislatif. Masyarakat Muslim Kecamatan Ilir Timur II Kota Palembang yang masuk pada Daerah Pemilihan (Dapil II) Kota Palembang, dengan jumlah pemilih sebanyak 60.139 orang melakukan proses pemilihan di 169 Tempat Pengumutan Suara (TPS) yang tersebar di 6 Kelurahan di Kecamatan Ilir Timur II Kota Palembang. (Sumber yang di dapat dari websait KPU).

\section{TINJAUAN LITERATUR}

Jurnal penelitian yang di tulis oleh Diana,Adam Idris, dan Achmad Djumlani, dengan judul Sikap Pemilih Pemula Terhadap Calon Legislatif Partai Politik Ditinjau dari Karakteristik Sosial (Studi Kasus Tingkat SMA di Samarinda). Hasil penelitian ini membuktikan bahwasannya tidak ada pengaruh jenis kelamin, agama, tempat tinggal, politomi partai terhadap sikap pemilih pemula dalam memilihi calon legislatif partai politik.

Penelitian yang ditulis Lintang Yunita Afriana, dengan judul Sikap Politik Anak Punk dalam Pemilihan Kepala Daerah Kabupaten Lampung Tengah Tahun 2015 (Studi di Kecamatan Bandar Jaya, Kabupaten Lampung Tengah). Hasil penelitian ini ditemukan bahwa anak Punk tidak memiliki pengetahuan tetapi dapat bersikap dandapat mengevaluasi pemilihan kepala daerah Kabupaten Lampung Tengah Tahun 2015, dan hasil penelitian ini juga membuktikan bahwa ternyata ada disorientasi tehadap masalah politik untuk kaum anak Punk.Pada Skripsi yang ditulis Isnaini Nurul Fajri, dengan judul Sikap Masyarakat Terhadap Partai Politik Islam (Studi Kasus Kelurahan Kopri Jaya, Kecamatan Sukarami,Kota Bandar Lampung).

Hasil penelitian ini menyatakan bahwa sikap masyarakat Kelurahan Kopri Jaya Kecamatan Sukarami Kota Bandar Lampung dengan sampel 85 responden yang memiliki sikap positif terhadap partai politik islam sebanyak 41 responden dengan presentase $48 \%$ dengan pertimbangan karena parpol islam memperjuangankan kepentingan masyarakat dan menggunakan flatfrom Al-Quran.Pada Jurnal penelitian yang ditulis Randika 
Sulistyo dan Damona K.Poespawardaja, dengan judul Gambaran Sikap Pemilih Muda Terhadap Pemilu Presiden dan Wakil Presiden Serta Sumber Informasi Utama Dari Internet. Hasil penelitian ini didapat bahwa terjadi perubahan sikap terhadap sumber informasi dari internet yang disetujui oleh pemilih muda pada tahun 2009, mereka cenderung mendapatkan informasi dari internet terkait kinerja Presiden dan Wakilnya pada periode pemerintahan sebelumnya sehingga mereka ingin berpartisipasi dalam pilpres tahun 2009.

Namun demikian, pada tahun 2014 para pemilih muda memiliki sikap yang lebih positif terhadap infromasi dari internet terkait Pilpres.Pada Jurnal Penelitian yang ditulis Jusuf Harsono, dengan judul Analisis Sikap Politik Warga Muhammadiyah Ponorogo Dalam Pilkada 2015. Hasil penelitian didapati bahwa sikap politik Organisasi Muhammadiyah pada Pilkada tahun 2015 ialah tidak melakukan politik praktis pada pelaksanaan pilkada dan sesuai dengan anturan pp Muhamadiyah yang mana Organisasi Muhamadiyah hanyamenganjurkan warga untuk memilih dengan pilihannya sendiri.Sedangkan yang membedakan dalam penelitian ini dengan penelitian sebelumnya adalah penelitian ini membahas tentang "Sikap Politik Masyarakat Muslim di Kecamatan Ilir Timur II Dalam Pemilihan UmumLegislatif Kota Palembang Tahun 2019” penelitian ini menggunakan metode kuantitatif yaitu penelitian yang berupa angka-angka dengan analisis menggunakan statistik deskriptif, dan pengunaan teori yang berbeda dari penelitian sebelumnya.

\section{METODE PENELITIAN}

Penelitian ini menggunakan metode kuantitatif yang bersifat deskriptif. Menurut Sugiyono (2017), penelitian kuantitatif adalah suatu penelitian dimana proses penggalian informasi diwujudkan dalam bentuk angka-angka yang diolah dengan statistika. Tujuan penelitian deskriptif ini untuk membuat pencandraan secara sistematis, faktual, dan akurat mengenai fakta-fakta dan sifa-sifat yang ada. Sehingga dapat merumuskan sebuah gambaran yang tersusun mengenai kejadian faktual.

\section{HASIL DAN PEMBAHASAN}

Berdasarkan hasil penelitian, bahwa dari 100 responden yang ada, 15 (15\%) memilih jawaban sangat tahu terhadap pelaksanaan pemilihan umum legislatif yang dilaksanakan pada tanggal 9 april tahun 2019, responden yang memilih jawaban tahu sebanyak 82 $(82 \%)$, responden yang memilih jawaban tidak tahu sebanyak $3(3 \%)$, dan responden yang memilih jawaban sangat tidak tahu sebanyak $0(0 \%)$. Diketahui bahwa ada $82(82 \%)$ yang memilih jawaban tahu, hal tersebut menunjukan bahwa masyarakat muslim di Kecamatan Ilir Timur II Sudah mengetahui adanya pemilihan umum legslatif yang di adakan pada tanggal 9 april tahun 2019. Ada 15 (15\%) masyarakat muslim di Kecamatan Ilir Timur II yang memilih jawaban sangat tahu ini menunjukan bahwa ada sebagian masyarakat yang sudah mengetahui di luar kepala mereka dengan ditunjukan mereka memilih jawaban sangat tahu artinya meraka sudah memiliki kesadaran politiknya. Sedangkan masyarakat yang memiih jawaban tidak tahu sebanyak $3(3 \%)$ ini menunjukan bahwa masih ada masyarakat muslim di Kecamatan Ilir Timur II masih belum mengetahui 
Ahmad Syafi'l Arief, M. Syawaluddin, Leo Andiguna, Sikap Politik Masyarakat Muslim Kecamatan Ilir Timur II Kota Palembang dalam Pileg Tahun 2019, Ampera: A Research Journal on Politics and Islamic Civilization, Vol. 1 No. 3, Agustus 2020

bahwasanya pada tanggal 9 april 2019, dilaksanakannya pemilihan umum legislatif Kota Palembang.

Tabel

Pengetahuan Subjek Tentang Maksud Dan Tujuan Dari Pelaksanaan Pemilu Tahun 2019

\begin{tabular}{|c|c|c|c|}
\hline No & Jawaban Subjek & Frekuensi & Presentase (\%) \\
\hline 1. & Sangat Tahu & 14 & 14 \\
\hline 2. & Tahu & 85 & 85 \\
\hline 3. & Tidak Tahu & 1 & 1 \\
\hline 4. & Sangat Tidak Tahu & 0 & 0 \\
\hline \multicolumn{2}{|c|}{ Total } & 100 & 100 \\
\hline
\end{tabular}

Berdasarkan hasil tabel di atas, dapat diketahui bahwa dari 100 subjek yang ada, $14(14 \%)$ memilih jawaban sangat tahu terhadap maksud dan tujuan dari pelaksanaan pemilihan umum legislatif yang dilaksanakan pada tanggal 9 april tahun 2019, subjek yang memilih jawaban tahu sebanyak 85 (85\%), subjek yang memilih jawaban tidak tahu sebanyak $1(1 \%)$, dan yang memilih jawaban sangat tidak tahu sebanyak $0(0 \%)$. Diketahui ada 85 (85\%) subjek yang memilih jawaban tahu, ini menunjukan sebagian besar bahwa masyarakat muslim sudah mengetahui maksud dan tujuan dari pelaksanaan pemilihan umum legislatif yang dilaksanakan pada tanggal 9 april tahun 2019 tetapi masih ragu apakah pengetahuanya itu benar. Sedangkan masyarakat muslim yang memilih jawaban sangat tahu ada 14 (14\%) menunjukan bahwa masyarakat yang mengetahui maksud dan tujuan dari pelaksanaan pemilihan umum legislatif yang dilaksanakan pada tanggal 9 april tahun 2019, sudah sangat tahu apa maksud dan tujuannya pelaksanaan pemilihan umum legislatif, tersebut. Selanjutnya masyarakat muslim yang memilih jawaban tidak tahu sebanyak 1 (1\%) ini menunjukan bahwa masih ada masyarakat yang blm mengetahui maksud dan tujuan dari pelaksanaan pemilihan umum legislatif yang dilaksanakan pada tanggal 9 april tahun 2019 tersebut.

Tabel

Pengetahuan Subjek Tentang Partai Politik Peserta Pemilu Legislatif Kota Palembang Tahun 2019

\begin{tabular}{|c|c|c|c|}
\hline No. & Jawaban Subjek & Frekuensi & Presentase (\%) \\
\hline 1. & Sangat Tahu & 9 & 9 \\
\hline 2. & Tahu & 88 & 88 \\
\hline 3. & Tidak Tahu & 3 & 3 \\
\hline 4. & Sangat Tidak Tahu & 0 & 0 \\
\hline \multicolumn{2}{|c|}{ Total } & 100 & 100 \\
\hline
\end{tabular}

Berdasarkan hasil tabel di atas, dapat diketahui bahwa dari 100 subjek yang ada, $9(9 \%)$ memilih jawaban sangat tahu terhadap Pengetahuan tentang partai Politik Peserta pemilihan umum legislatif Kota Palembang tahun 2019, subjek yang memilih jawaban tahu sebanyak 88 (88\%), subjek yang memilih jawaban tidak tahu sebanyak $3(3 \%)$, dan yang memilih jawaban sangat tidak tahu sebanyak 0 (0\%). Diketahui ada $88(88 \%)$ masyarakat muslim yang telah memilih jawaban tahu, ini menunjukan bahwah 
masyarakat muslim di Kecamatan Ilir Timur II Kota Palembang sudah mengetahui siapa saja partai perserta pemilu legislatif Kota Palembang, akan tetapi masyarakat masih ragu dengan jawabannya dikarenakan pengetahuanya itu benar atau tidak. Sedangkan ada 9 (9\%) masyarakat muslim yang telah memilih jawaban sangat tahu, ini menunjukan bahwah masyarakat muslim di Kecamatan Ilir Timur II Kota Palembang sudah mengetahui siapa saja partai perserta pemilu legislatif Kota Palembang dan sudah yakin dengan pengetahuanya tersebut. Selanjutnya ada 3 (3\%) masyarakat muslim yang telah memilih jawaban tidak tahu, ini menunjukan bahwah masyarakat muslim di Kecamatan Ilir Timur II Kota Palembang masih ada yang blum mengetahui siapa saja partai peserta pemilu Kota Palembang.

Tabel

Pengetahuan Subjek Tentang Siapa Yang Menjadi Calon Anggota Legislatif Kota Palembang Tahun 2019

\begin{tabular}{|c|c|c|c|}
\hline No & Jawaban Subjek & Frekuensi & Presentase (\%) \\
\hline 1. & Sangat Tahu & 6 & 6 \\
\hline 2. & Tahu & 84 & 84 \\
\hline 3. & Tidak Tahu & 10 & 10 \\
\hline 4. & Sangat Tidak Tahu & 0 & 0 \\
\hline \multicolumn{2}{r|}{ Total } & 100 & 100 \\
\hline
\end{tabular}

Berdasarkan hasil tabel di atas, dapat diketahui bahwa dari 100 subjek yang ada, $6(6 \%)$ memilih jawaban sangat tahu terhadap Pengetahuan tentang siapa saja yang menjadi calon angota legislatif dalam pemilihan umum legislatif Kota Palembang tahun 2019, subjek yang memilih jawaban tahu sebanyak 84 (84\%), subjek yang memilih jawaban tidak tahu sebanyak $10(10 \%)$, dan yang memilih jawaban sangat tidak tahu sebanyak $0(0 \%)$.

Tabel

Pengetahuan Subjek Tentang Siapa Penyelengaraa Pemilihan Umum Legislatif Kota Palembang Tahun 2019

\begin{tabular}{|c|c|c|c|}
\hline No. & Jawaban Subjek & Frekuensi & Presentase (\%) \\
\hline 1. & Sangat Tahu & 8 & 8 \\
\hline 2. & Tahu & 84 & 84 \\
\hline 3. & Tidak Tahu & 7 & 7 \\
\hline 4. & Sangat Tidak Tahu & 1 & 1 \\
\hline \multicolumn{2}{|c|}{ Total } & 100 & 100 \\
\hline
\end{tabular}

Berdasarkan hasil tabel di atas, dapat diketahui bahwa dari 100 subjek yang ada, $8(8 \%)$ memilih jawaban sangat tahu terhadap Pengetahuan tentang siapa penyelengaraa pemilihan umum legislatif legislatif Kota Palembang tahun 2019, subjek yang memilih jawaban tahu sebanyak 84 (84\%), subjek yang memilih jawaban tidak tahu sebanyak 7 (7\%), dan yang memilih jawaban sangat tidak tahu sebanyak 1 (1\%). Sehingga dapat disimpulkan bahwa ada $84(84 \%)$ masyarakat muslim di Kecamatan Ilir Timur II Kota Palembang yang menjawab tahu, artinya masyarakat muslim sudah mengetahui siapa yang menjadi penyeenggara pemilu legislatif tahun 2019, akan tetapi blm yakin dengan 
pengetahuannya. Sedangkan ada $8(8 \%)$ masyarakat muslim di Kecamatan Ilir Timur II Kota Palembang yang menjawab sangat tahu,ini menujukan bahwa masyarakat sudah sangat mengetaui siapa yang menjadi penyelenggara pemilu legislatif tahun 2019 tersebut. Selanjutnya ada 7 (7\%) masyarakat muslim di Kecamatan Ilir Timur II Kota Palembang yang menjawab tidak tahu, ini menunjukan bahwa masih ada masyarakat muslim yang blm mengetahui siapa yang menjadi penyelengarra pemilu legislatif tahun 2019. Dan ada 1 (1\%) masyarakat muslim di Kecamatan Ilir Timur II Kota Palembang yang menjawab sangat tidak tahu, ini menunjukan bahwa masih ada masyarakat muslim yang sangat blm mengetahui siapa yang menjadi penyelengarra pemilu legislatif tahun 2019, dan kurangnya kesadarannya tentang politik.

Tabel

Pengetahuan Subjek Tentang proses Penyelenggaran Pemilihan Umum Legislatif Kota Palembang Tahun 2019

\begin{tabular}{|c|c|c|c|}
\hline No & Jawaban Subjek & Frekuensi & Presentase (\%) \\
\hline 1. & Sangat Tahu & 9 & 9 \\
\hline 2. & Tahu & 77 & 77 \\
\hline 3. & Tidak Tahu & 14 & 14 \\
\hline 4. & Sangat Tidak Tahu & 0 & 0 \\
\hline \multicolumn{2}{|c|}{ Total } & 100 & 100 \\
\hline
\end{tabular}

Berdasarkan hasil tabel di atas, dapat diketahui bahwa dari 100 subjek yang ada, 9 (9\%) memilih jawaban sangat tahu terhadap pengetahuan tentang proses penyelenggaraan pemilihan umum legislatif legislatif Kota Palembang tahun 2019, subjek yang memilih jawaban tahu sebanyak 77 (77\%), subjek yang memilih jawaban tidak tahu sebanyak 14 (14\%), dan yang memilih jawaban sangat tidak tahu sebanyak 0 (0\%). Sehingga dapat disimpulkan bahwa ada 77 (77\%) masyarakat muslim di Kecamatan Ilir Timur II Kota Palembang yang sudah mengetahui proses penyeenggaraan pemilu legislatif tahun 2019, akan tetapi blm yakin dengan pengetahuannya. Dan ada 9 (9\%) masyarakat muslim di Kecamatan Ilir Timur II Kota Palembang yang menjawab sudah sangat mengetahui proses penyeenggaraan pemilu legislatif tahun 2019 dan kesadaran politiknya sangat tinggi. Sedangkan ada 14 (14\%) masyarakat muslim di Kecamatan Ilir Timur II Kota Palembang yang menjawab tidak tahu tentang proses penyeenggaraan pemilu legislatif tahun 2019, dikarenakannya kurangnya pengetahuan politik dan kurangnya sosialisasi dari penyelengara mengenai pemilu legislatif tahun 2019.

Tabel

Kepercayaan Subjek Terhadap Hak Pilih Masyarakat dalam Pemilu Legislatif Kota Palembang Tahun 2019 Digunakan Dengan Jujur

\begin{tabular}{|c|c|c|c|}
\hline No. & Jawaban Subjek & Frekuensi & Presentase (\%) \\
\hline 1. & Sangat Percaya & 3 & 3 \\
\hline 2. & Percaya & 68 & 68 \\
\hline 3. & Tidak Percaya & 28 & 28 \\
\hline
\end{tabular}


Ahmad Syafi'l Arief, M. Syawaluddin, Leo Andiguna, Sikap Politik Masyarakat Muslim Kecamatan Ilir Timur II Kota Palembang dalam Pileg Tahun 2019, Ampera: A Research Journal on Politics and Islamic Civilization, Vol. 1 No. 3, Agustus 2020

\begin{tabular}{|c|c|c|c|}
\hline 4. & Sangat Tidak percaya & 1 & 1 \\
\hline \multicolumn{2}{|c|}{ Total } & 100 & 100 \\
\hline
\end{tabular}

Berdasarkan hasil tabel di atas, dapat diketahui bahwa dari 100 subjek yang ada, $3(3 \%)$ memilih jawaban sangat percaya terhadap kepercayaan masyarakat terhadap hak pilih masyarakat dalam pemilu legislatif Kota Palembang Tahun 2019 digunakan dengan jujur, subjek yang memilih jawaban percaya sebanyak 68 (68\%), subjek yang memilih jawaban tidak percaya sebanyak 28 (28\%), dan yang memilih jawaban sangat tidak percaya sebanyak $1 \quad(1 \%)$. Sehingga dapat di simpulkan bahwa masyarakat muslim yang memilih jawaban percaya sebanyak $68(68 \%)$ ini menunjukan bahwa masyarakat muslim di Kecamatan Ilir Timur II Kota Palembang percaya terhadap hak pilih mereka digunakan dengan jujur. Dan ada 3 (3\%) masyarakat muslim yang memilih jawaban sangat percaya ini menunjukan bahwa masyarakat muslim sangat percaya terhadap hak pilih mereka digunakan dengan jujur. Sedangkan ada 28 (28\%) masyarakat muslim yang memilih jawaban tidak percaya terhadap hak pilih meraka digunakan dengan jujur, ini menunjukan masih banyak masyarakat muslim di Kecamatan Ilir Timur II Kota Palembang yang masih belum percaya hak pilih meraka digunakan dengan jujur. Dan ada $1(1 \%)$ masyarakat muslim yang memilih jawaban sangat tidak percaya terhadap hak pilih meraka digunakan dengan jujur ini berarti bahwa masih belum tersampaikannya aspirasi masyarakat tentang pemilu yang bersih dan jurdil.

\section{Tabel}

Persepsi Masyarakat Terhadap Visi Misi Calon Anggota Legislatif Kota Palembang Sudah Sesuai Dengan Harapan Masyarakat

\begin{tabular}{|c|c|c|c|}
\hline No & Jawaban Subjek & Frekuensi & Presentase (\%) \\
\hline 1. & Sangat Sesuai & 4 & 4 \\
\hline 2. & Sesuai & 66 & 66 \\
\hline 3. & Tidak Sesuai & 28 & 28 \\
\hline 4. & Sangat Tidak Sesuai & 2 & 2 \\
\hline \multicolumn{2}{|c|}{ Total } & 100 & 100 \\
\hline
\end{tabular}

Berdasarkan hasil tabel di atas, dapat diketahui bahwa dari 100 subjek yang ada, $4(4 \%)$ memilih jawaban sangat sesuai terhadap visi misi calon anggota legislatif Kota Palembang Sudah Sesuai dengan harapan masyarakat, subjek yang memilih jawaban Sesuai sebanyak 66 (66\%), subjek yang memilih jawaban tidak sesuai sebanyak 28 $(28 \%)$, dan yang memilih jawaban sangat tidak Layak sebanyak $2(2 \%)$. Sehingga dapat di simpulkan bahwa ada $66(66 \%)$ masyarakat muslim memilih jawaban sesuai, ini menunjukan bahwa visi misi calon anggota legislatif Kota Palembang Sudah Sesuai dengan harapan masyarakat, sehingga masyarakat sangat menaruh harapan yang besar terhadap calon anggota legislatif Kota Palembang agar memenuhi aspirasinya. Dan ada 4 (4\%) masyarakat muslim memilih jawaban sangat sesuai, ini menunjukan bahwa visi misi calon anggota legislatif Kota Palembang sudah sangat sesuai dengan harapan masyarakat, sehingga masyarakat berharap banyak agar calon anggota legislatif Kota Palembang memperjuangan nasib mereka. Selanjutnya ada $28(28 \%)$ masyarakat muslim memilih jawaban tidak sesuai, ini menunjukan bahwa visi misi calon anggota legislatif 
Kota Palembang belum sesuai dengan harapan masyarakat di karenakan harapan mereka begitu besar terhadap calon anggota legislatif Kota Palembang. Dan ada 2 (2\%) masyarakat muslim memilih jawaban tidak sesuai, ini menunjukan bahwa visi misi calon anggota legislatif Kota Palembang belum sangat sesuai dengan harapan masyarakat di karenakan visi dan misi yang di usung oleh calon anggota legislatif di anggap belum memikirkan keentingan banyak orang.

Berdasarkan hasil penelitian dapat diketahui bahwa masyarakat muslim di Kecamatan Ilir Timur II memiliki sikap politik yang positif terhadap Pemilihan Umum Legislatif Kota Palembang Tahun 2019. Sikap politik ini dibentuk berdasarkan tiga komponen yakni kognitif, afektif dan evaluatif. Sedangkan bentuk sikap sendiri dapat berupa positif, netral dan negatif.

Sikap positif yaitu ketika masyarakat muslim mengetaui, percaya, setuju terhadap dirinya sebagai pemilih, kadidat, penyelenggara,visi dan misi para calon anggota legislatif. Sikap netral ketika masyarakat muslim mengetaui terhadap dirinya sebagai pemilih cukup peduli, kadidat, penyelenggara,visi dan misi para calon anggota legislatif. Sikap negatif yaitu ketika masyarakat muslim tidak mengetahui, tidak percaya, tidak setuju dan tidak peduli terhadap dirinya sebagai pemilih, kadidat penyelenggara,visi dan misi para calon anggota legislatif.

Sikap terbentuk dalam perkembangan individu karena adanya interaksi sosial. Pada interaksi sosial, terjadi hubungan saling mempengaruhi di antara individu yang satu dengan individu yang lainya, terjadi hubungan timbal balik yang turut mempengaruhi pola perilaku masing-masing individu sebagai anggota masyarakat.

Pada interaksi sosialnya, individu bereaksi membuat pola sikap tertentu terhadap berbagai objek psikologis yang dihadapinya. Faktor yang mempengaruhi pembentukan sikap tersebut diantaranya yaitu pengalaman pribadi, pengaruh orang lain yang dianggap penting, kebudayaan, media masa. Begitu juga yang terjadi pada masyarakat muslim di Kecamatan Ilir Timur II Kota Palembang terhadap pemilihan umum legislatif tahun 2019. Berdasarkan hasil pengamatan, hal tersebut terjadi karena di pengaruhi oleh faktor berikut:

Menurut azwar, apa yang telah dan sedang dialami akan membentuk dan mempengaruhi penghayatan terhadap stimulus sosial. Tanggapan akan menjadi salah satu dasar terbentuknya sikap. Untuk mempunyai tanggapan tersebut seseorang harus memiliki pengalaman yang berkaitan dengan objek psikologisnya. Sikap politik masyarakat muslim di Kecamatan Ilir Timur II Kota Palembang terhadap pemilihan umum legislatif tahun 2019 menunjukan sikap politik yang positif.

Selain itu, orang lain disekitar menjadi salah satu faktor sosial yang mempengaruhi sikap seseorang. Orang yang memiliki pengaruh dalam menentukan sikap pada masyarakat muslim ialah orang sekitar, tokoh agama dan tokoh masyarakat, sehingga sikap politik di Kecamatan Ilir Timur II terhadap pemilihan umum legislatif Kota Palembang tahun 2019 ialah sikap positif dikarenakan orang yang dianggap penting dan memiliki pengaruhnya.

Kebudayaan yang dianut masyarakat muslim di Kecamatan Ilir Timur II Kota Palembang ialah kebudayaan yang agamis di karenakan 91\% mayarakat muslim di Kecamatan Ilir Timur II menganut agama islam, sehingga budaya. 


\section{KESIMPULAN}

Dapat disimpulkan bahwa komponen sikap politik terdiri dari komponen kognitif, afektif, evaluatif, Berdasarkan hasil penelitian, masyarakat muslim memang kurang mendapatkan pendidikan politik dan sosialisasi politik, sehingga masyarakat muslim masih ada yang menjawab tidak tahu kapan proses pemilihan anggota legislatif kota palembang tahun 2019, hal tersebut terjadi di karenakan kurangnya sosialisasi dari penyelengara pemilu yang ada di Kota Palembang. Tetapi masyarakat masih bisa menentukan sikap nya dalam pemilihan umum legislatif Kota Palembang tahun 2019. 


\section{DAFTAR PUSTAKA}

Ahmadi, Abu. (2002). Psikologi Sosial. Rineka Cipta. Jakarta.

Azwar, Saifuddin. (2017). Metode Penelitian. Yogyakarta: Pustaka Pelajar.

Firmanzah. (2008). Marketing Politik: Antara Pemahaman dan Realitas. Yayasan Obor Indonesia Jakarta.

Mikail, Kiki. "PEMILU DAN PARTAI POLITIK DI INDONESIA: Menanti Kebangkitan Partai Politik Islam Di Tahun 2019". Tamaddun: Jurnal Kebudayaan dan Sastra Islam 15, no. 1 (April 7, 2016): 107-148. Accessed January 2 , 2021. http://jurnal.radenfatah.ac.id/index.php/tamaddun/article/view/444.

Rahmat,jalaludin. (2001). Psikologi Komunikasi. Bandung. PT. Remaja Rosdakarya.

Rush, Michael. (2000). SosiologiPolitik. Raja GrafindoPersada. Jakarta

Sandi Jhon Alfari, (2019), Lembaga Adat dan Hak-Hak Adat Masyarakat Dayak Dalam Pusaran Politik. Tanggerang Selatan: An1mage.

Sarina, DKK,(2016). Pendidikan Pancasila dan Kewargaan. Yogyakarta: Deepublish.

Septiyanti, A. (2020). Political Marketing dalam Pemilihan Gubernur Sumatera Selatan Tahun 2018 (Studi Kasus Tim Pemenangan Herman Deru-Mawardi Yahya di Kota Palembang). Ampera: A Research Journal on Politics and Islamic Civilization, 1(1), 14-23. Retrieved from http://jurnal.radenfatah.ac.id/index.php/Ampera/article/view/5184

Subakti, Ramlan.(2010). Memahami Ilmu Politik. Jakarta. PT.Gramedia Widiasarana Indonesia.

Sugiyono (2017). Metode Penelitian Kualitatif dan Kuantitatif , Bandung:Penerbit Alfabeta

Syarbaini Syahrial,DKK (2002), Sosiologi dan Politik, Jakarta: Ghalia Indonesia Winarno Budi,(2007), Sistem Politik Indonesia Era Reformasi. Yogyakarta: Medpress 